\title{
DNA Barcoding and Phylogenetic Relationships of Selected South Indian Freshwater Fishes Based on mtDNA COI Sequences
}

\section{Manickam Raja* and Pachiappan Perumal}

Department of Biotechnology, Periyar University, Periyar Palkalai Nagar, Salem - 636 011, Tamil Nadu, India

*Corresponding author: Manickam Raja, Department of Biotechnology, School of Biosciences, Periyar University, Periyar Palkalai Nagar, Salem- 636 011, Tamil Nadu, India, Tel: +91 9894277036; E-mail: wetlandraja@gmail.com

Receiving date: Aug 22, 2017; Acceptance date: Sep 12, 2017; Publication date: Sep 15, 2017

Copyright: (c) 2017 Raja M, et al. This is an open-access article distributed under the terms of the Creative Commons Attribution License, which permits unrestricted use, distribution, and reproduction in any medium, provided the original author and source are credited.

\begin{abstract}
DNA barcoding is an effective tool for the identification of species representing diverse taxa especially through the sequence analysis of mitochondrial cytochrome c oxidase subunit I (COI) gene. In the present study, DNA barcodes were generated from 46 species of freshwater fishes covering the Orders Cypriniformes, Siluriformes, Synbranchiformes and Perciformes representing 30 genera under 9 families. All the samples were collected from diverse sites which also includes some endemic species. A total of $47 \mathrm{COI}$ sequences were generated. After amplification and sequencing of 678 base pair fragment of $\mathrm{COI}$, primers were trimmed which invariably generated a 635 base pair barcode sequence. The average Kimura two-parameter (K2P) distances within-species, genera, families, and orders were $0.32 \%, 8.40 \%, 14.50 \%$, and $18.65 \%$, respectively. DNA barcode discriminated congeneric species without any confusion. The present study strongly supports the efficiency of $\mathrm{COI}$ as an ideal marker for DNA barcoding of selected freshwater fishes.
\end{abstract}

Keywords: Barcoding; COI; Indian freshwater fishes; mtDNA; Phylogeny

\section{Introduction}

India is rich in fishery resources as it inhabits about 2508 fish species [1] of which the 856 are freshwater occupants [2,3]. The fishes are the most diverse vertebrate in world and about $40 \%$ of them live in freshwater. India is one of the mega biodiversity countries in the world and occupies the ninth position in terms of freshwater mega biodiversity and contributed $11.72 \%$ of the globe fish biodiversity [4]. However, the actual number of fish species found in India is still not accurately documented because of prevailing taxonomic confusion [5] due to inadequate exploration, indiscernibility among cryptic forms coupled with species ambiguity in the taxonomic keys [6]. As a result, many species have been considered as cryptic and some of which may also be dormant $[6,7]$. Therefore, for legible characterization of Indian freshwater fishes, there is a vital need of species scrutiny using advanced molecular methods. Hence, there is an urgent need for the assessment of Indian freshwater fish species through DNA barcoding.

DNA barcoding is a promising technique for species identification using a short mitochondrial DNA sequence of COI gene [8]. This technique involves the analysis of the sequence diversity of a 50 segment mitochondrial COI gene to identify species [9]. Of late, DNA barcoding method has been extensively followed for species identification as well as species discovery in various groups of organism [10,11]. Effectiveness of DNA barcoding has now been validated for many groups of animals [12] and among them fishes being one of the most extensively studied groups $[13,14]$.

In recent years, several such molecular studies have been conducted on members of this group to better understand their relationships and to develop more accurate taxonomic classifications based on phylogeny [15-25]. Use of COI gene for barcode is considered to be suitable marker to discriminate the closely related species of fishes [26-29]. But the challenge in use of small DNA barcode (only 655bp) based phylogenetic study is selection of a nearly perfect nucleotide substitution model for the dataset, so that the weakest evolutionary signal can be correctly detected [30]. However, a comprehensive assessment of DNA barcodes of Indian freshwater fishes is limited, though a similar study has been done for the selected Indian freshwater fishes by Lakra [8]. Therefore, the present study reported additional DNA barcoding of 46 commercially important Indian freshwater fish species belonging to 30 genera under 9 families and 4 orders.

\section{Materials and Methods}

\section{Sample collection and morphological identification}

The tissue and voucher specimens of 46 species ( 9 families) were collected from different riverine systems of south India namely from Cauvery and Bhavani river systems. Approximately $100 \mathrm{mg}$ of muscle tissue and fin clips from two to five individuals of each species were preserved in 95\% ethanol until used. The species identification and confirmation were carried out using standard literature $[31,32]$. The valid nomenclatural names were adopted as per the Catalogue of Fishes of the California Academy of Sciences [1,33]. The live specimens were photographed with Canon 1100 Digital SLR Camera and later preserved in $7 \%$ formalin solution for future reference. Table 1 represents specimen details and GenBank accession numbers. 
Citation: Raja M, Perumal P (2017) DNA Barcoding and Phylogenetic Relationships of Selected South Indian Freshwater Fishes Based on mtDNA COI Sequences. J Phylogenetics Evol Biol 5: 184. doi:10.4172/2329-9002.1000184

Page 2 of 6

\begin{tabular}{|c|c|c|c|c|c|}
\hline S. no. & Order & Family & Species & Voucher No. & Accession no. \\
\hline 1 & Cypriniformes & Cyprinidae & Salmophasia bacaila (Hamilton, 1822) & PUMNH 08/2013 & KX266823 \\
\hline 2 & & & Barilius canarensis (Jerdon, 1849) & PUMNH 30/2013 & KX230848 \\
\hline 3 & & & Barilius gatensis (Valenciennes, 1844) & PUMNH 31/2013 & KX230845 \\
\hline 4 & & & Barilius bendelisis (Hamilton, 1807) & PUMNH32/2013 & KX230846 \\
\hline 5 & & & Barilius bakeri (Day, 1865) & PUMNH01/2013 & KX230847 \\
\hline 6 & & & Danio rerio (Hamilton, 1822) & PUMNH76 /2013 & KX266821 \\
\hline 7 & & & Danio rerio (Hamilton, 1822) & PUMNH77 /2013 & KX266822 \\
\hline 8 & & & $\begin{array}{l}\text { Devario aequipinnatus (McClelland, } \\
\text { 1839) }\end{array}$ & PUMNH 04/2013 & KX289313 \\
\hline 9 & & & Devario malabaricus (Jerdon, 1849) & PUMNH02 /2013 & KX529835 \\
\hline 10 & & & Rasbora daniconius (Hamilton, 1822) & PUMNH 34/2013 & KX239494 \\
\hline 11 & & & Esomus danricus (Hamilton, 1822) & PUMNH06 /2014 & KX266826 \\
\hline 12 & & & $\begin{array}{l}\text { Amblypharyngodon mola (Hamilton, } \\
\text { 1822) }\end{array}$ & PUMNH 28/2013 & KX266827 \\
\hline 13 & & & Tor khudree (Sykes, 1839) & PUMNH 47/2013 & KX550003 \\
\hline 14 & & & $\begin{array}{l}\text { Neolissocheilus } \\
\text { (McClelland, 1839) }\end{array}$ & PUMNH 48/2013 & KX266828 \\
\hline 15 & & & Systomus sarana (Hamilton, 1822) & PUMNH 49/2013 & KX239499 \\
\hline 16 & & & $\begin{array}{l}\text { Dawkinsia filamentosa (Valenciennes, } \\
\text { 1844) }\end{array}$ & PUMNH 50/2013 & KX230844 \\
\hline 17 & & & Dawkinsia arulius (Jerdon, 1849) & PUMNH 06/2013 & KX239496 \\
\hline 18 & & & $\begin{array}{l}\text { Puntius amphibius (Valenciennes, } \\
\text { 1842) }\end{array}$ & PUMNH 07/2013 & KX529836 \\
\hline 19 & & & Puntius sophore (Hamilton, 1822) & PUMNH03/2014 & KX289308 \\
\hline 20 & & & Haludaria fasciata (Jerdon, 1849) & PUMNH 51/2013 & KX550002 \\
\hline 21 & & & Pethia narayani (Hora, 1937) & PUMNH 07/2014 & KX289310 \\
\hline 22 & & & Barbodes carnaticus (Jerdon, 1849) & PUMNH 52/2013 & KX239492 \\
\hline 23 & & & Hypselobarbus dubius (Day, 1867) & PUMNH 53/2013 & KX266817 \\
\hline 24 & & & $\begin{array}{l}\text { Hypselobarbus curmuga (Hamilton, } \\
\text { 1807) }\end{array}$ & PUMNH 13/2014 & KX266819 \\
\hline 25 & & & $\begin{array}{l}\text { Hypselobarbus kurali (Menon \& Rema } \\
\text { Devi, 1995) }\end{array}$ & PUMNH 23/2014 & KX266820 \\
\hline 26 & & & Hypselobarbus kolus (Sykes, 1839) & PUMNH 39/2014 & KX266818 \\
\hline 27 & & & $\begin{array}{ll}\text { Hypselobarbus } & \text { micropogon } \\
\text { (Valenciennes, 1842) } & \end{array}$ & PUMNH 72/2014 & KX266813 \\
\hline 28 & & & $\begin{array}{l}\text { Hypselobarbus periyarensis (Raj, } \\
\text { 1941) }\end{array}$ & PUMNH 93/2014 & KX266814 \\
\hline 29 & & & Osteochilichthys nashii (Day, 1868) & PUMNH 62/2013 & KX239498 \\
\hline 30 & & & $\begin{array}{l}\text { Osteochilichthys thomassi (Day, } \\
\text { 1877) }\end{array}$ & PUMNH 19/2014 & KX239497 \\
\hline 31 & & & Osteobrama cotio (Hamilton, 1822) & PUMNH 23/2014 & KX550004 \\
\hline
\end{tabular}


Citation: Raja M, Perumal P (2017) DNA Barcoding and Phylogenetic Relationships of Selected South Indian Freshwater Fishes Based on mtDNA COI Sequences. J Phylogenetics Evol Biol 5: 184. doi:10.4172/2329-9002.1000184

Page 3 of 6

\begin{tabular}{|c|c|c|c|c|c|}
\hline 32 & & & Laboe bata (Hamilton, 1822) & PUMNH 12/2013 & KX289314 \\
\hline 33 & & & Labeo rohita (Hamilton, 1822) & PUMNH 14/2013 & KX266835 \\
\hline 34 & & & Garra mullya (Sykes, 1839) & PUMNH 57/2013 & KX239490 \\
\hline 35 & & & Garra bicornuta (Narayan Rao, 1920) & PUMNH 15/2013 & KX289309 \\
\hline 36 & & & Garra mcClellandi (Jerdon, 1849) & PUMNH 56/2013 & KX239495 \\
\hline 37 & & Cobitidae & $\begin{array}{l}\text { Lepidocephalichthys } \quad \text { thermalis } \\
\text { (Valenciennes, 1846) }\end{array}$ & PUMNH 54/2013 & KX266825 \\
\hline 38 & & & $\begin{array}{l}\text { Lepidocephalichthys guntea } \\
\text { (Hamilton, 1822) }\end{array}$ & PUMNH 18/2014 & KX266824 \\
\hline 39 & & & Botia striata Narayan Rao, 1920 & PUMNH 13/2014 & KX575850 \\
\hline 40 & & & Bhavania australis (Jerdon, 1849) & PUMNH 12/2014 & KX289311 \\
\hline 41 & & Balitoridae & Nemacheilus guentheri Day, 1867 & PUMNH 15/2014 & KX289312 \\
\hline 42 & Siluriformes & Bagridae & Mystus bleekeri (Day, 1877) & PUMNH 19/2013 & KX266834 \\
\hline 43 & & Siluridae & Ompok bimaculatus (Bloch, 1794) & PUMNH 22/2013 & KX239493 \\
\hline 44 & & Sisoridae & Glyptothorax gracilis (Gunther, 1864) & PUMNH 29/2014 & KX289315 \\
\hline 45 & Synbranchiformes & Mastacembelidae & $\begin{array}{l}\text { Mastacembelus armatus (Lacepede, } \\
\text { 1800) }\end{array}$ & PUMNH 38/2013 & KX575851 \\
\hline 46 & Perciformes & Nandidae & Nandus nandus (Hamilton, 1822) & PUMNH 70/2013 & KX266833 \\
\hline 47 & & Gobiidae & Glossogobius giuris (Hamilton, 1822) & PUMNH 43/2013 & KX239491 \\
\hline
\end{tabular}

Table 1: List of freshwater fish species barcoded along with GenBank accession numbers.

\section{Amplification and sequencing}

Genomic extractions were taken from fin clips, preserved in $>95 \%$ ethanol using Invitrogen's "Pure Link Genomic DNA Mini Kit" following the manufactures instructions. COI amplification was carried out in $25-\mu \mathrm{L}$ reaction mixtures containing $1 \mu \mathrm{l}$ template DNA, $1 \mathrm{X}$ reaction buffer, $2.5 \mathrm{mM} \mathrm{MgCl}_{2}, 2.5 \mathrm{mM}$ dNTPs, $0.5 \mu \mathrm{l}$ of each primer, and 0.2 U TaqDNA polymerase in a PTC-200 (Bio-Rad, USA) PCR machine. The reaction mixtures were preheated at $94^{\circ} \mathrm{C}$ for $5 \mathrm{~min}$, followed by 50 cycles of amplification $\left(94^{\circ} \mathrm{C}\right.$ for $45 \mathrm{sec}, 48^{\circ} \mathrm{C}$ for $45 \mathrm{sec}$, and $72^{\circ} \mathrm{C}$ for $60 \mathrm{sec}$ ), and a final extension at $72^{\circ} \mathrm{C}$ for $6 \mathrm{~min}$. The COI gene was amplified using the universal primer set: The primers used for the amplification of the COI gene were: Fish F1-5'TCAACCAACCACAAAGACATTGGCAC-3' and Fish R1-5'TAGACTTCTGGGTGGCCAA AGAATCA-3' [34]. Sequencing was performed using Big Dye Terminator on ABI 3500 Genetic Analyzer (Applied Biosystems, Foster City, CA). The PCR products were visualized on $1.2 \%$ agarose gels and the most intense products were selected for sequencing. Products were labeled using the BigDye Terminator V.3.1 Cycle Sequencing Kit (Applied Biosystems, Inc., Foster City, CA) and sequenced bidirectionally using an ABI 3730 capillary sequencer following instructions of the manufacturer. One individual of each species was used for the nucleotide sequence analyses.

\section{Sequence analysis}

Sequences were aligned using Clustal W [35] and then submitted to GenBank. The extent of sequence difference between species was calculated by averaging pair-wise comparisons of sequence difference across all individuals. Pair-wise evolutionary distance among haplotypes was determined by the Kimura 2-Parameter method [36] using the software program MEGA 3 (Molecular Evolutionary Genetics Analysis, MEGA Inc., Englewood, NJ) [37]. The NeighborJoining (NJ) tree was constructed using MEGA 3 and to verify the robustness of the internal nodes of $\mathrm{NJ}$ tree, and bootstrap analysis was carried out using 1000 pseudo replications.

\section{Results}

\section{Genetic divergence and phylogenetic analysis}

A total of 47 sequences were generated from 46 freshwater fish species. Sequence alignment of COI gene after trimming of primers yielded 635 nucleotide base pairs per taxon. All the sequences showed simplicity and un-ambiguity, and no insertions, deletions, or stop codons were observed in any of the sequences. The sequence analysis revealed average nucleotide frequencies as $\mathrm{A}=26.00 \%, \mathrm{~T}=29.80 \%$, $\mathrm{G}=26.4 \%$. and $\mathrm{C}=17.90 \%$. The average $\mathrm{K} 2 \mathrm{P}$ distances in percentage among the different taxonomic levels were analyzed (Table 2). The average transitional pairs $\left(\mathrm{si}^{1 / 472}\right)$ were more frequent than average transversional pairs $\left(\mathrm{sv}^{1 / 4} / 46\right)$ with an average ratio of 1.30 . The average genetic distances within order, family, genus and species were $18.65 \%$, $14.50 \%, 8.40 \%$, and $0.32 \%$ respectively. The overall average genetic distance among all the species was $23.90 \%$. 
Citation: Raja M, Perumal P (2017) DNA Barcoding and Phylogenetic Relationships of Selected South Indian Freshwater Fishes Based on mtDNA COI Sequences. J Phylogenetics Evol Biol 5: 184. doi:10.4172/2329-9002.1000184

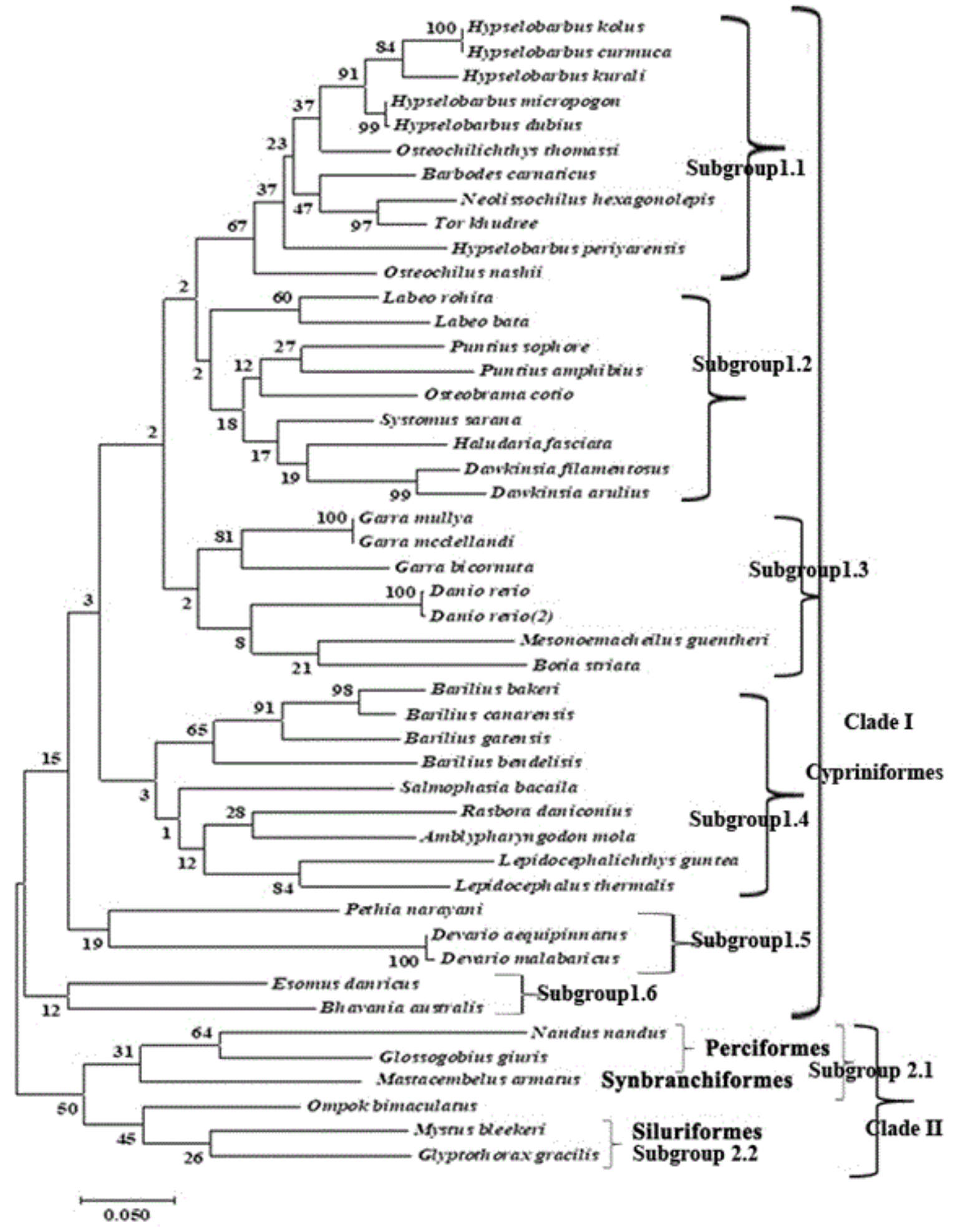

Figure 1: The Neighbor-joining tree for 47 species of freshwater fishes based on COI sequences. Note: Scale bar indicates the genetic distance.

The phylogram was divided into two main clades with high bootstrap support $(>50 \%)$ (Figure 1$)$. The clade I was subdivided into six separated subgroups: subgroup 1.1 includes 11 species belong to 6 genus (Hypselobarbus, Osteochilichthys, Barbodes, Neolissochilus, Tor and Osteochilus) of the family Cyprinidae. 
Page 5 of 6

\begin{tabular}{|c|c|c|c|c|}
\hline Taxa & Min dist (\%) & $\begin{array}{l}\text { Mean } \\
(\%)\end{array}$ & Max dist (\%) & $\begin{array}{l}\text { Standard error } \\
\text { (SE) }\end{array}$ \\
\hline $\begin{array}{l}\text { Within } \\
\text { species }\end{array}$ & 0 & 0.32 & 0.77 & 0.003 \\
\hline $\begin{array}{l}\text { Within } \\
\text { genus }\end{array}$ & 0.12 & 8.4 & 14.32 & 0.007 \\
\hline $\begin{array}{l}\text { Within } \\
\text { family }\end{array}$ & 0.73 & 14.5 & 25.6 & 0.01 \\
\hline $\begin{array}{l}\text { Within } \\
\text { order }\end{array}$ & 5.2 & 18.65 & 29.5 & 0.016 \\
\hline
\end{tabular}

Table 2: Summary of genetic divergences of different taxonomic levels (based on the K2P distance model).

Subgroup 1.2 includes 9 species belonging to 6 genera (Labeo, Puntius, Osteobramma, Systomus, Haludaria, Dawkinsia) of the family Cyprinidae. Subgroup 1.3 includes 6 species belonging to 4 genera (Garra, Danio, Mesonemacheilus, Botia) of the family Cyprinidae. Subgroup 1.4 includes 9 species belonging to 5 genera (Barilius, Salmophasia, Rasbora, Amblypharyngodon, Lepidocephalichthys) of the family Cyprinidae. Subgroup 1.5 includes 3 species belonging to 2 genera (Pethia, Devario) of the family Cyprinidae. Subgroup 1.6 consists of 2 species belonging to 2 genera (Esomus, Bhavania). At the genus level all the species showed monophyly with high BT support. The clade II was divided into two subgroups. The Subgroup 2.1 consists of 3 species from two orders, Nandus nandus and Glossogobius giuris belonging to the order Perciformes and Mastacembelus aramatus belonging to the order Synbranchiformes. Subgroup 2.2 consists of 3 species of the genera; Ompak, Mystus, Glyptothorax belonging to the order Siluriformes.

\section{Discussion}

During DNA barcoding by Hebert et al. [38], the sequencing of a $\sim 650 \mathrm{bp}$ region of the mitochondrial cytochrome oxidase I gene (COI), has been proven to be extremely an effective method for discriminating fish species $[28,34,39]$. Interestingly, recent research has illustrated some straightforward benefits from the use of standardized species-specific molecular tags derived from COI gene for species-level identifications [40]. DNA barcoding analysis has clearly discriminated freshwater fish species from India [8] Canada [28] and Mexico and Guatemala [39]. Presently, we have effectively used partial COI genes as DNA barcode in 46 freshwater fish species from south Indian waters representing 4 orders (Cypriniformes, Siluriformes, Perciformes and Synbranchiformes) representing 9 families and 30 genera. The universal primers amplified the target region in all 46 species, thus generating 47 COI barcodes of $635 \mathrm{bp}$ and no insertions, deletions, stop codons or NUMTs were observed in any sequence, which support the hypothesis that all the amplified sequences derive from a functional mitochondrial COI sequences. And the present findings are in line with the previous reports [34]. Although the primary objective of DNA barcoding is to identify species, phylogeographic structure among COI sequences within species became evident. DNA barcoding pursues to provide a convenient, accurate and valid tool for species identification, and any candidate gene must suit this qualification. Use of a single, universal gene has many advantages, especially as barcoding applications expand to ecological questions and in the identification of illegally imported parts of organisms [41]. The study indicates that the standard barcoding marker, COI, can identify fish

species $[42,43,44]$. The barcode sequences clearly discriminated all the studied freshwater fish species along with the apparent phylogenetic resolution. Although intra- and inter-specific genetic divergences overlap, tree-based methods can distinguish species in unidentified samples. For the ecologist and taxonomist alike, DNA barcoding would provide a powerful tool for the correct species identification, biodiversity assessments and locating the occurrence of cryptic species $[45,46]$.

\section{Acknowledgements}

The first author (M.R) is grateful to the SERB - DST (Government of India), for providing the Startup Research Grant under Young Investigator Scheme (File No. DST No. SB/YS/LS-36/2013) and UGC, New Delhi for the grant of Dr. DSK Postdoctoral Fellowship (File No.F. 42/2006 (BSR)/BL/ 1516/0408), to carry out this study.

\section{References}

1. Eschmeyer WN, Fricke R (2012) Catalog of fishes electronic version (20 December, 2013). Electronic database accessible at http:// research.calacademy.org/research/ichthyology/ catalog/ fishcatmain.asp/.

2. Menon AGK (1999) Check list-Fresh water fishes of India. Records of the Zoological Survey of India. Misc Publ 175: 1-366.

3. Froese R, Pauly (2012) Fish Base. World Wide Web Electronic Publication Available: www.fishbase.org Accessed: 2012 Dec 28.

4. Leveque C, Oberdorff T, Paugy D, Stiassny MLJ, Tedesco PA (2008) Global diversity of fish (Pisces) in freshwater. Hydrobiologia 198: 545-567.

5. Hoagland KE (1996) The Taxonomic Impediment and the Convention on Biodiversity. ASC News 24: 66-67.

6. Pethyagoda R, Kottelat M (1994) Three new species of fishes of the genera Osteochilichthys (Cyprinidae), Travancoria (Balitoridae) and Horabagrus (Bagridae) from the Chalakudy River Kerela India. J South Asian Nat Hist 1: $97-116$.

7. Darshan A, Anganthoibi N, Vishwanath W (2010) Redescription of the striped catfish Mystus carcio (Hamilton) (Siluriformes: Bagridae). Zootaxa 2475: 48-54.

8. Lakra WS, Singh M, Goswami M, Gopalakrishnan A, Lal KK (2015) DNA barcoding Indian freshwater fishes. Mitochondrial DNA 1-8.

9. Hebert PD, Penton EH, Burns JM, Janzen DH, Hallwachs W (2004) Ten species in one: DNA barcoding reveals cryptic species in the neotropical skipper butterfly Astraptes fulgerator. Proc Natl Acad Sci USA 101: 14812-14817.

10. Hajibabaei M (2012) The golden age of DNA meta systematics. Trends Genet 28: 535-537.

11. Mendonca A, Cunha A, Chakrabarti R (2012) Natural Resources, Sustainability and Humanity: A Comprehensive View, Springer.

12. Waugh J (2007) DNA barcoding in animal species: progress, potential and pitfalls. Bioessays 29: 188-197.

13. Becker S, Hanner R, Steinke D (2011) Five years of FISH-BOL: brief status report. Mitochondrial DNA 22: 3-9.

14. Ward RD (2012) FISH-BOL: a case study for DNA barcodes. Methods Mol Biol 858: 423-439.

15. Liu H, Chen Y (2003) Phylogeny of the East Asian cyprinids inferred from sequences of the mitochondrial DNA control region. Can J Zool 81: 1938-1946.

16. Saitoh K, Sado T, Mayden RL, Hanzawa N, Nakamura K (2006) Mitogenomic evolution and interrelationships of the Cypriniformes (Actinopterygii: Ostariophysi): the first evidence toward resolution of higher-level relationships of the world's largest freshwater fish clade based on 59 whole mitogenome sequences. J Mol Evol 63: 826-841. 
Citation: Raja M, Perumal P (2017) DNA Barcoding and Phylogenetic Relationships of Selected South Indian Freshwater Fishes Based on mtDNA COI Sequences. J Phylogenetics Evol Biol 5: 184. doi:10.4172/2329-9002.1000184

Page 6 of 6

17. Ruber L, Kottelat M, Tan $\mathrm{HH}, \mathrm{Ng}$ P, Britz R (2007) Evolution of miniaturization and the phylogenetic position of Paedocypris, comprising the world's smallest vertebrate. BMC Evol Biol 7: 38.

18. Slechtova V, Bohlen J, Tan HH (2007) Families of Cobitoidea (Teleostei; Cypriniformes) as revealed from nuclear genetic data and the position of the mysterious genera Barbucca, Psilorhynchus, Serpenticobitis and Vaillantella. Mol Phylogenet Evol 44: 1358-1365.

19. Conway KW, Chen WJ, Mayden RL (2008) The "celestial pearl danio" is a miniature Danio (ss) (Ostariophysi: Cyprinidae): evidence from morphology and molecules. Zootaxa 1686: 1-28.

20. Chen WJ, Mayden RL (2009) Molecular systematics of the Cyprinoidea (Teleostei: Cypriniformes), the world's largest clade of freshwater fishes: further evidence from six nuclear genes. Mol Phylogenet Evol 51: 544-549.

21. Mayden RL, Chen WJ, Bart HL, Doosey MH, Simons AM (2009) Reconstructing the phylogenetic relationships of the earth's most diverse clade of freshwater fishes-order Cypriniformes (Actinopterygii: Ostariophysi): a case study using multiple nuclear loci and the mitochondrial genome. Mol Phylogenet Evol 51: 500-514.

22. Mayden RL, Chen WJ (2010) The world's smallest vertebrate species of the genus Paedocypris: a new family of freshwater fishes and the sister group to the world's most diverse clade of freshwater fishes (Teleostei: Cypriniformes). Mol Phylogenet Evol 57: 152-175.

23. Yang L, Mayden RL, Sado T, He SP, Saitoh K (2010) Molecular phylogeny of the fishes traditionally referred to Cyprinini sensustricto (Teleostei: Cypriniformes). Zool Scr 39: 527-550.

24. Tang KL, Agnew MK, Chen WJ, Hirt MV, Sado T (2010) Systematics of the subfamily Danioninae (Teleostei: Cypriniformes: Cyprinidae). Mol Phylogenet Evol 57: 189-214.

25. Tang KL, Agnew MK, Chen WJ, Hirt MV, Raley ME (2011) Phylogeny of the gudgeons (Teleostei: Cyprinidae: Gobioninae). Mol Phylogenet Evol 6: 103-124.

26. Frati F, Simon C, Sullivan J, Swofford DL (1997) Evolution of the mitochondrial cytochrome oxidase II gene in Collembola. J Mol Evol 44: 145-158.

27. Steinke D, Vences M, Salzburger W, Meyer A (2005) A software tool for DNA barcoding using distance methods. Phil Trans Roy Soc London Series B 360: 1847-1857.

28. Hubert N, Hanner R, Holm E, Mandrak NE, Taylor E (2008) Identifying Canadian freshwater fishes through DNA barcodes. PLoS One 3: e2490.

29. Lakra WS, Verma MS, Goswami M, Lal KK, Mohindra V (2011) DNA barcoding Indian marine fishes. Mol Ecol Resour 11: 60-71.

30. Sullivan J, Markert JA, Kilpatrick CW (1997) Phytogeography and molecular systematics of the Peromyscusaztecus species group (Rodentia: Muridae) inferred using parsimony and likelihood. Syst Biol 46: 426-440.

31. Talwar PK, Jhingran AG (1991) Inland fishes of India and adjacent countries. Oxford \& IBH Pub Co.
32. Jayaram KC (2010) The freshwater fishes of the Indian Region. Narendra Publishing House, New Delhi India 616.

33. Pethiyagoda R, Meegaskumbura M, Maduwage K (2012) A synopsis of the South Asian fishes referred to Puntius (Pisces: Cyprinidae). Ichth Explo Fresh 23: 69-95.

34. Ward RD, Zemlac TC, Innes BH, Last PR, Hebert PD (2005) DNA barcoding Australia's fish species. Philos Trans R Soc Lond B Biol Sci 360: 1847-1857.

35. Thompson JD, Gibson TJ, Plewniak F, Jeanmougin F, Higgins DG (1997) The CLUSTAL X windows interface: Flexible strategies for multiple sequence alignment aided by quality analysis tools. Nucleic Acids Res 25: 4876-4882.

36. Kimura M (1980) A simple method for estimating evolutionary rates of base substitutions through comparative studies of nucleotide sequences. J Mol Evol 16: 111-120.

37. Kumar S, Tamura K, Nei M (2004) MEGA3: Integrated software for molecular evolutionary genetics analysis and sequence alignment. Brief Bioinform 5: 150-163.

38. Hebert PD, Cywinska A, Ball SL, deWaard JR (2003) Biological identifications through DNA barcodes. Proc Biol Sci 270: 313321.

39. Valdez-Moreno M, Ivanova NV, Elias-Gutierrez M, Contreras-Balderas S, Hebert PD (2009) Probing diversity in freshwater fishes from Mexico and Guatemala with DNA barcodes. J Fish Biol 74: 377-402.

40. Pradhan V, Kamble Y, Ladniya V, Mogul M (2015) An overview of species identification by DNA barcoding. Int J Curr Microbiol App Sci 4: 127-140.

41. Xia Y, Gu HF, Peng R, Chen Q, Zheng YC (2012) COI is better than $16 \mathrm{~S}$ rRNA for DNA barcoding Asiatic salamanders (Amphibia: Caudata: Hynobiidae). Mol Ecol Resour 12: 48-56.

42. Smith M, Poyarkovjr NA, Hebert PD (2008) DNA barcoding: CO1 DNA barcoding amphibians: take the chance, meet the challenge. Mol Ecol Resour 8: 235-246.

43. Vences M, Thomas M, Bonett RM, Vieites DR (2005) Deciphering amphibian diversity through DNA barcoding: chances and challenges. Philos Trans R Soc Lond B Biol Sci 360: 1859-1868.

44. Vences M, Thomas M, Vander Meijden A, Chiari Y, Vieites DR (2005) Comparative performance of the 16S rRNA gene in DNA barcoding of amphibians. Front Zool 2: 5.

45. Vences M, Chiari Y, Teschke M, Glaw F (2008) Which frogs are out there? A preliminary evaluation of survey techniques and identification reliability of Malagasy amphibians. A Conservation Strategy for the Amphibians of Madagascar-Monografie XLV: 233-252.

46. Vieites DR, Wollenberg KC, Andreone F, Kohler J, Glaw J (2009) Vast underestimation of Madagascar's biodiversity evidenced by an integrative amphibian inventory. Proc Natl Acad Sci USA 106: 8267-8272. 